\title{
Discovery Learning based on Natural Phenomena to Improve Students' Science Process Skills
}

\author{
Rudi Haryadi ${ }^{1, a)}$, Heni Pujiastuti ${ }^{2, b)}$ \\ ${ }^{1}$ Program Studi Pendidikan Fisika, Universitas Sultan Ageng Tirtayasa \\ ${ }^{2}$ Program Studi Pendidikan Matematika, Universitas Sultan Ageng Tirtayasa \\ $\bigotimes:{ }^{a)}$ rudiharyadi@untirta.ac.id, $\left.{ }^{b}\right)$ henipujiastuti@untirta.ac.id
}

\begin{abstract}
The purpose of this research is to find out the science process skills of students through discovery learning. The process of science is essential for students to have because it is the process of forming science. Science process skills can accustom students to learning through scientific work processes and systematic work. The research method uses a quasi-experiment with one group pretest-posttest design. This study does not use a comparison class, because it already uses a preliminary test so that the magnitude of the effect or effect of using discovery learning can be known with certainty. In this study, research subjects were first given a pre-test (pretest) to find out the extent of the students' initial abilities before being given physics learning by using discovery learning. After the initial test is given, then the student is given treatment, namely learning physics by using discovery learning. After completing physics learning with discovery learning, then all students are given a final test (posttest) to determine the extent of the effect of physics learning by using discovery learning on students' science process skills. The instrument used in this study was a science process skills test on the material elasticity and Hooke law, in the form of 20 multiple-choice tests and tested on 30 students in Prisma City High School. Each question evaluates aspects of conclusions, observations, identification, predictions, and interpretation of data. The results of the analysis show an increase in observational indicators from 39.95 to 66.62 , concluding from 53.86 to 69.4 , identifying from 36.6 to 73.3 , predicting from 39.43 to 68.31 and interpreting from 73.3 to 98.3 . Based on the results of the analysis, the learning of physics-based on natural phenomena through discovery learning models can improve students' science process skills.
\end{abstract}

Keywords: discovery learning, students' science process skills, elasticity and Hooke's law

\section{INTRODUCTION}

As one of the subjects in the family of science, physics will not be separated from things related to natural phenomena. Natural phenomena are non-artificial events in the view of physics (Horio, 2017). Natural phenomena can occur due to two factors, the first due to natural factors, then the second because of artificial or human-made factors. Natural phenomena are also closely related to the environment (Schachner, Zhu, Li, \& Kelemen, 2017).

The existence of the environment can be used as a source of learning. In this case, the environment includes society, physical environment, available materials, natural phenomena, natural events, and events that occur in society. By utilizing nature or the environment, students are expected to be able to bring experience in their environment so that they can be synchronized with learning material, so as to be able to provide an understanding of specific symptoms or behavior through scientific observation. 
The characteristics of the topics of elasticity and Hooke's law and their application in the context of phenomena in everyday life are very interesting to discuss. The topic of elasticity and Hooke's law can be found on four-wheeled or two-wheeled vehicles. The characteristic of the topic of elasticity and Hooke's law is that, if pulled, it will return to normal. Besides, it also has a function as a safety comfort while driving. Based on these topics, students can find their learning based on natural phenomena that can improve science process skills.

With the right treatment, nature can be a unique, interesting and efficient learning media. In this case, students can do learning based on their own observations through natural phenomena. The right learning model must certainly support the application of natural phenomenon-based learning. The learning model used in this study is discovery learning.

The discovery learning model is a teaching model that regulates teaching in such a way that students acquire knowledge that they have not yet known, but not through notice, some or all found themselves (Kistner, Vollmeyer, Burns, \& Kortenkamp, 2016). In discovery learning, activities or learning are designed so that students can find concepts and principles through their mental processes. In finding concepts, students make observations, classify, make guesses, explain, draw conclusions and so on to find some concepts or principles (Yamashita et al., 2016).

Discovery learning is a series of learning activities that involve maximally all the ability of students to search and investigate systematically, critically, and logically so that they can find their own knowledge, attitudes, and skills as a manifestation of behavior change (Huang, Huang, \& Chuang, 2015). Discovery learning is a mental process where students can assimilate a concept or principle. The mental processes in question include: Observing, digesting, understanding, classifying, making guesses, explaining, measuring, making conclusions and so on. With this technique, students are left to find themselves or experience their own mental processes; the teacher only guides and gives instructions (Dedonno, 2016). Thus discovery learning is learning that involves students in the process of mental activity through the exchange of opinions, by discussing, reading on their own, and trying on their own, so that children can learn on their own (Price \& Falcão, 2011).

The discovery learning model is a teaching model that focuses on student activities in learning. In the learning process with this model, the teacher only acts as a guide and facilitator who directs students to find concepts, propositions, procedures, algorithms and the like. Three main features of discovery learning models, namely: (1) Exploring and solving problems to create, combine and generalize knowledge; (2) Student-centered; (3) Activities to combine new knowledge and existing knowledge (Saab, Joolingen, \& Hout-wolters, 2007).

The advantages of discovery learning models are: students will understand basic concepts and ideas better, help and develop memories and transfers to new learning process situations, encourage students to think and work on their initiative, encourage students to think intuition and formulate their hypotheses, giving intrinsic decisions, the learning process situation becomes more aroused, and the learning process includes fellow aspects of the student towards the formation of a whole person (Bakker, 2018). Besides, this model is also able to increase student appreciation levels; the possibility of students learning by utilizing various types of learning resources can develop individual talents or skills. The discovery learning model is present as a learning model that invites students to have life skills in the $21^{\text {st }}$ century.

Based on the results of research conducted by (Yusuf \& Wulan, 2015) that the application of discovery learning models of shared and webbed cohesiveness can improve students' science process skills. Other results also show that the web-based physics learning media using the guided discovery learning approach can overcome limitations in the teaching and learning process and can facilitate students in understanding physics material (Kalatting et al., 2015). The guided discovery learning model can also help the learning process with games in the surrounding environment (Lingyi, 2010). Correspondingly, discovery learning can be used as an orientation of video game exploration for teaching and learning activities (Thorngate, 2018). Furthermore, the learning model using discovery learning can improve the ability of cognitive (Dedonno, 2016).

Entering the $21^{\text {st }}$ century, currently, the learning objectives include the development of the domain of attitudes, knowledge, and skills elaborated for each education unit (Makaramani, 2015). These three domains are based on different psychological processes. The attitude aspect is obtained through the activities of accepting, implementing, appreciating, living, and practicing. Knowledge is obtained 
through the activity of remembering, understanding, applying, analyzing, evaluating, and creating. Skills are obtained through the activity of observing, asking, trying, reasoning, presenting, and creating. Therefore, science process skills are owned and developed in students.

Science process skills are the ability of students to apply scientific models in understanding, developing and discovering science (Nilawati \& Akbar, 2017). Science process skills can be improved through a learning process that is designed in such a way that students discover facts, build concepts and theories with intellectual skills and scientific attitudes of students themselves. Students are allowed to be directly involved in scientific activities as done by scientists (Kurniawati \& Sukardiyono 2018).

Science Process Skills are very important for each student as a provision to use scientific models in developing science and are expected to develop the knowledge they already have (Malik, 2015). Science process skills are all directed scientific skills (both cognitive and psychomotor) that can be used to find a concept or principle or theory, to develop concepts that already existed before, or to make a denial of an invention (Haryadi, 2019).

Science process skills need to be trained and developed in the learning process, because it has several functions, including helping students learn to develop their minds, allowing students to make discoveries, improve memory, give intrinsic satisfaction when the child has succeeded in doing something, and help students learn science concept (Susanti, 2017). Practicing science process skills in learning is one way to optimize student learning outcomes. Because by practicing science process skills, students will find their own knowledge through experiments so that the subject matter will be easily understood and remembered in a relatively long time.

Some efforts have been made to improve the science process skills. Research results (Lati, Supasorn, \& Promarak, 2012) show that learning outcomes and science process skills can be improved through inquiry learning. The results of the study also explain that science process skills can be improved by question and answer or exposure to the final learning outcomes (Downing \& Gifford, 1996). The results of other studies report that using cell-regulated learning can improve students' science process skills through laboratory metacognitive skills (Saribas \& Bayram, 2009).

The novelty of this research is the learning of physics-based on natural phenomena through discovery learning. Students are guided to study outside to see the events that are around related to the topic of elasticity and Hooke's law. Then students are given time to observe and discover problems themselves in the learning process. So with an independent learning experience, students are expected to have science process skills.

This research activity aims to assess the differences in the effect of physics learning based on natural phenomena through discovery learning models on improving students' science process skills. Through this research, researchers want to know that the application of physics phenomena based on natural phenomena through discovery learning models can improve students' science process skills.

\section{METHODS}

The study was conducted at Senior High School Prisma in Serang city. The research method used a quasi-experiment with one group pretest-posttest design. This study does not use a comparison class, because it has used the initial test so that the magnitude of the effect or influence of the use of discovery learning can be known with certainty. In this study, the subjects of the study were first given a pretest test to determine the extent of students' initial abilities before being given physical learning using discovery learning. After being given the initial test, then the students were given treatment, namely physics learning by using discovery learning. After completing physics learning with discovery learning, then to all students given the final test (posttest) to determine the extent of the influence of learning physics by using discovery learning on student skills. In simple terms, the research design used can be seen in FIGURE 1 below.

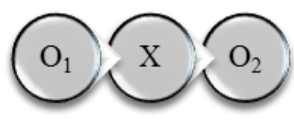

FIGURE 1. One group pretest-posttest design 
Information:

$\mathrm{O}_{1}$ : pre-test

$\mathrm{O}_{2}$ : post-test

$\mathrm{X}$ : Treatment (physics learning by using discovery learning)

This research activity aims to assess the differences in the influence of physics learning based on natural phenomena through discovery learning models on improving students' science process skills. Through this research, researchers want to know that the application of physics learning based on natural phenomena through discovery learning models can improve students' science process skills.

In terms of population limits, this study includes using a finite or finite population. The reason is that the population has a clear quantitative boundary and also has limited characteristics, namely the population of the XI grade students of Senior High School Prisma in Serang city who are studying the subject of Hooke's law and elasticity.

In sampling, researchers used purposive sampling techniques, namely sampling techniques with certain considerations. The chosen sample class is XI MIPA as a research sample, with consideration of students of class XI MIPA are students who rarely conduct investigation models during the learning process.

The instrument used in this study was a test of science process skills after participating in learning activities. In research, research instruments are needed that meet certain requirements. This study used a multiple-choice question test instrument. The instrument was given twice, namely during the pretest and posttest. The multiple-choice questions are numbered 20. Each question evaluates in terms of concluding, observing, identifying and manipulating variables, predicting, and interpreting data.

After obtaining the pretest and posttest results, the researcher used the normalized gain score formula (N-Gain) in order to find out the improvement of students' science process skills. The existence of a normalized gain score (N-Gain) gives an idea of improving students' science process skills between before and after treatment. The formula used is a formula that has been developed by Hake and can be seen in FIGURE 2 below (Hake, 1998).

\section{$N$-Gain $=\frac{\text { skor posttest siswa-skor pratest siswa }}{\text { skor posttest maksimal-skor pretest siswa }}$}

FIGURE 2. N-gain score

Then, to determine the criteria for improving students' science process skills before and after learning, it can be seen in TABLE 1 below (Hake, 1998).

TABLE 1. N-Gain Classification

\begin{tabular}{lcc}
\hline & N-Gain & Improvement Classification \\
\hline $\mathrm{g}>0,70$ & High \\
$0,30<\mathrm{g} \leq 0,70$ & Medium (enough) \\
$\mathrm{g} \leq 0,30$ & Low \\
\hline
\end{tabular}

\section{RESULTS AND DISCUSSION}

Based on the results of the study, obtained data results, namely pretest and posttest data. Furthermore, the results of students' science process skills can be seen in FIGURE 3 below. 


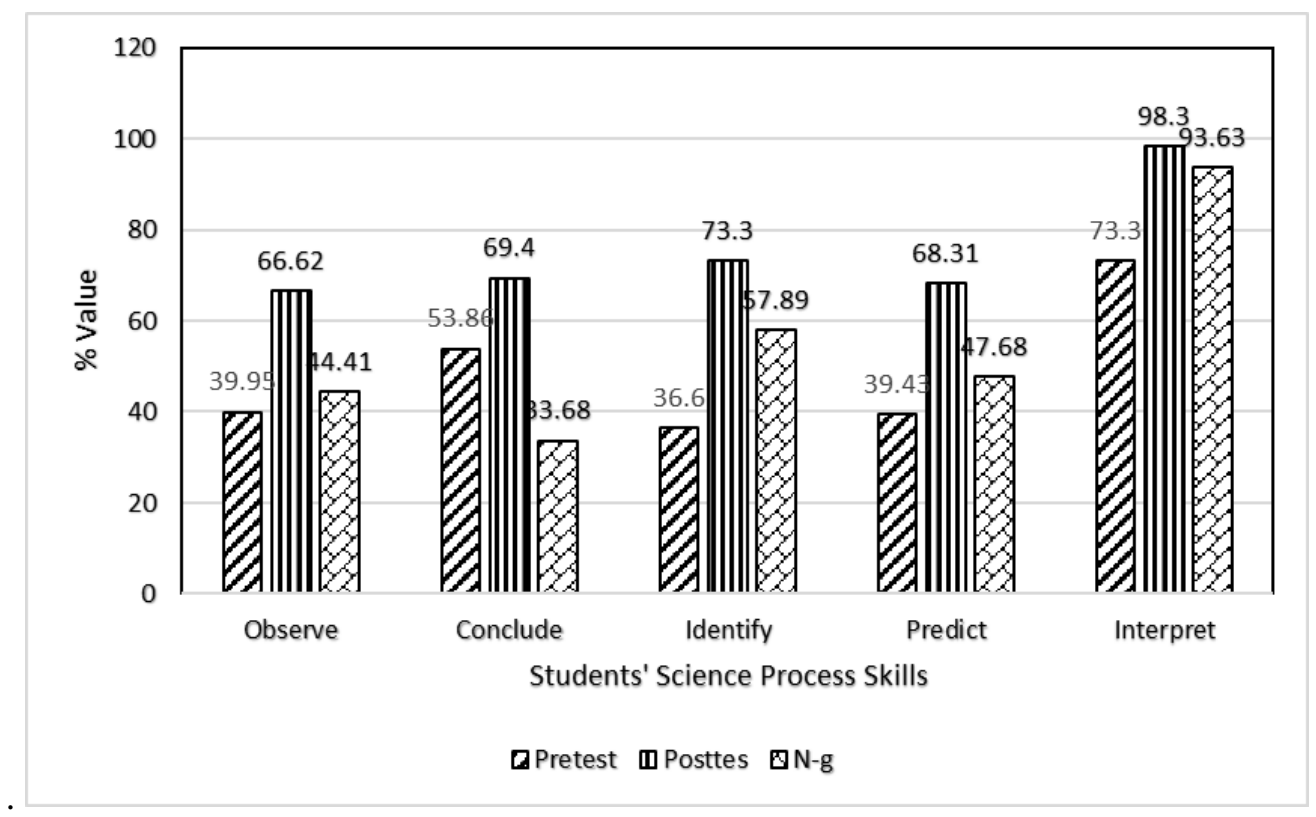

FIGURE 3. Students' science process skills

From FIGURE 3 it can be seen that the learning process of physics-based on natural phenomena through this discovery learning model can improve students' science process skills. In the observation stage, students experienced an increase from $39.95 \%$ to $66.62 \%$. N-gain obtained was $44.41 \%$ or 0.44 . Based on the $\mathrm{N}$-gain results obtained, the observing aspect is 0.44 , including the moderate or sufficient category. Observing is the process of gathering data about a phenomenon or event using its senses. To be able to master the skill of observing, students must use as many of their senses as possible, which are seeing, hearing, feeling, smelling and tasting. Thus it can gather relevant and adequate facts. The aspect of observing is very important to have students, because by having sufficient value on the aspect of observing, then students can observe the events that are around well

Furthermore, the conclusions obtained from $53.86 \%$ to $69.4 \%$. N-gain obtained is $33.68 \%$ or 0.33 . These results indicate that the ability to conclude is included in the sufficient category. Concluding skills are one aspect of critical thinking skills. Conclusion skills are activities of the human mind based on the knowledge it has to reach new understandings. Conclusion skills bring students to be able to describe and understand various aspects gradually to arrive at a new formula, which is a conclusion.

Then, at the identification stage, it was obtained from $36.6 \%$ to $73.3 \%$. Then, the N-gain obtained is $57.89 \%$ or 0.57 . From the results of the $\mathrm{N}$-gain, the ability to identify is included in the Fair category. From these results, students can identify problems that occur during the physics learning process. The ability to identify is one aspect of science process skills that students must possess. Students can explore their information, then investigate, and find out the problems that exist.

After the ability to identify, then the ability to predict. Based on FIGURE 3, the predicted results show that the value obtained from $39.43 \%$ to $68.31 \%$. Then the $\mathrm{N}$-gain results obtained $47.68 \%$ or 0.47 . N-gain results show that the ability to predict students from science process skill questions is in the sufficient category. Based on the results obtained, students can reasonably predict problems that will be encountered in everyday life, in this case, related to the topic of elasticity and Hooke's law.

Finally, the ability to interpret the results obtained from $73.3 \%$ to $98.3 \%$. The $\mathrm{N}$-gain result shows $93.63 \%$ or equal to 0.93 . The results of $\mathrm{N}$-gain indicate that the ability to interpret is high. This means students can already interpret the science process skills from the topics of elasticity and Hooke's law. Students can combine several data to make a conclusion that is considered correct.

Based on FIGURE 3, the average N-gain results from science process skills are using discovery learning based on natural phenomena, as shown in TABLE 2 below. 
TABLE 2. N-gain average

\begin{tabular}{lcc}
\hline \multicolumn{1}{c}{ The aspect of Science Process Skills } & Value & Category \\
\hline Observe & 0.44 & Enough \\
Conclude & 0.33 & Enough \\
Identify & 0.57 & Enough \\
Predict & 0.47 & Enough \\
Interpret & 0.93 & High \\
\hline Average & 0.54 & Enough \\
\hline
\end{tabular}

From TABLE 2 it can be seen that the average $\mathrm{N}$-gain of science process skills using natural phenomenon-based discovery learning has a value of 0.54 , which means it is included in the sufficient category. It can be said that discovery learning based on natural phenomena can improve students' scientific process skills on the topic of Hooke's law and elasticity. This is in line with the research that has been done about learning models through discovery learning. The results of the study showed that there was an increase in students' science process skills after applying a guided discovery learning model on temperature and heat material (Astra \& Wahidah, 2017). Furthermore, the results of the study also resulted in the improvement of students' science process skills through the application of the discovery learning model by using shared and webbed type integrated learning on Global Warming material (Yusuf \& Wulan, 2015). The next researcher also suggested that the development of webbased physics learning media using a guided discovery learning approach could overcome limitations in the teaching and learning process and could facilitate students in understanding physics material (Kalatting et al., 2015). In another study, it was also produced that the module developed, based on Discovery Inquiry, had met the module criteria so that it could be used in independent learning (Fitri \& Handoko, 2015).

In this study, through the discovery of leaning learning process models, generally through several stages, including the following. Simulation is the first stage in the discovery learning model. At this stage, the teacher shows a glimpse of the video regarding material elasticity and Hooke's law. The process of discovery learning that occurs at this stage is that students discover concepts about various elasticities and their application after seeing the video that has been given. It seems that students are very concerned about the video, so students know the description of the material to be learned. At the first meeting of this learning, the teacher divided the students into six randomly selected groups. The next step is the problem statement. The teacher guides students in groups to identify problems that are on the student discussion sheet. Then students are guided to make hypotheses about applying elasticity in the surrounding environment and daily life. The teacher encourages students to convey their ideas through the questions asked so students can think in making hypotheses for questions about how the relationship of the concepts of material elasticity and Hooke's law to phenomena that are in the environment. At the second learning meeting, the next stage is data collecting, where students will discuss the influence of style on changes in spring length. Then students are given a student discussion sheet that contains five indicators of science process skills to be examined, namely observing, concluding, identifying and manipulating variables, predicting, and interpreting data.

Through discovery learning, in filling out student discussion sheets, students are allowed to fill each column independently by observing the environment and discovering for themselves. Students are also allowed to observe various symptoms or phenomena around them regarding Hooke's elasticity and Law. The teacher explores students' knowledge through direct and indirect observation. Besides, in order to provide appreciation and a sense of responsibility, each student in each group has their duties and functions. Students observe various symptoms or phenomena around them. The teacher explores students' knowledge through direct and indirect observation.

At the next meeting, the data collecting stage is still ongoing. This time the students carried out Hooke's legal experiments using springs/rubber, ruler, hanging loads, and static with the determined group. The teacher's role is to facilitate and guide students when practicing, which is to provide tools and materials used. The researcher guides students to make experimental steps and helps students if there are difficulties in conducting experiments. The implementation of the experiment went well because the students had understood the experimental procedures carried out. Students also look happy 
when conducting experiments because they not only learn theory but can immediately practice it in the form of experiments.

The next stage is data processing, where students write observations on the observation table on the student worksheet. Students hold discussions with their respective groups in working on student worksheets and when discussion students ask questions to the teacher about things that have not been understood. The teacher does not directly answer the question, but the teacher does a question and answers with the students to answer the questions that are conveyed so that students are motivated to think in conveying their ideas.

Next is verification, where students analyze the results of the discussion at the first meeting and experiment at the second meeting. Students also conclude whether the results of the experiment are following the hypothesis made previously. At this stage, the teacher is allowed to ask questions to students to analyze the results so that specific conclusion is obtained from the experiments conducted. Students look enthusiastic when answering questions from the teacher and are seen as active in question and answer activities to draw experimental conclusions.

With the stages of learning, such as simulation, problem statements, data collecting, data processing, and verification, can help students be aroused to think critically, have high enthusiasm, and have high science process skills. Learning also becomes active because students have more roles in the classroom when the learning process takes place.

\section{SUMMARY}

Based on the results of the analysis of research data, the conclusion in this study is that physics learning based on natural phenomena through discovery learning models can be used to improve students' science process skills on the concepts of elasticity and Hooke's law. This can be seen from the results of each aspect or indicator achieved from the science process skills. It can also be seen that the average $\mathrm{N}$-gain of each aspect of science process skills shows that there is a sufficient category of 0.54 . This shows that the discovery learning model based on natural phenomena can improve students' science process skills in physics learning, namely the concept of elasticity and Hooke's law.

\section{REFERENCES}

Astra, I. M., \& Wahidah, R. S 2017. Peningkatan Keterampilan Proses Sains Peserta Didik Melalui Model Guided Discovery Learning Kelas XI MIPA pada Materi Suhu dan Kalor. Jurnal Penelitian \& Pengembangan Pendidikan Fisika, vol. 3, no. 2, pp. 181-190.

Bakker, A 2018. Discovery learning : zombie , phoenix , or elephant? Instructional Science, vol. 46, no. 1, pp. 169-183. https://doi.org/10.1007/s11251-018-9450-8

Dedonno, M. A 2016. The in fl uence of IQ on pure discovery and guided discovery learning of a complex real-world task. Learning and Individual Differences, vol. 49, pp. 11-16. https://doi.org/10.1016/j.lindif.2016.05.023

Downing, J. E., \& Gifford, V 1996. An Investigation of Preservice Teachers ' Science Process Skills and Questioning Strategies Used During a Demonstration Science Discovery Lesson. Journal Of Elementary Science Education, vol. 8, no. 1, pp. 64-75.

Fitri, U. R., \& Handoko, E 2015. Pengembangan Modul Berbasis Discovery-Inquiry untuk Fisika SMA Kelas XII Semester 2. Jurnal Penelitian \& Pengembangan Pendidikan Fisika, 1, 47-54.

Hake, R. R 1998. Interactive-engagement versus traditional methods: A six-thousand-student survey of mechanics test data for introductory physics courses. American Journal of Physics, vol. 66, no. 1, pp. 64-74. https://doi.org/10.1119/1.18809 
Haryadi, R, Vita, M, Utami, S, Ihsanudin, Setiani, Y \& Suherman, A 2019. Briquettes production as teaching aids physics for improving science process skills Briquettes production as teaching aids physics for improving science process skills. Journal of Physics: Conference Series, vol. 1157, no. 3. https://doi.org/10.1088/1742-6596/1157/3/032006

Horio, M 2017. Fluidization in Natural Phenomena. Chemistry, Molecular Sciences and Chemical Engineering. https://doi.org/10.1016/B978-0-12-409547-2.12185-7

Huang, T. C., Huang, C., \& Chuang, Y 2015. Change discovery of learning performance in dynamic educational environments. Telematics And Informatics, vol. 33, no. 3, pp. 773-792. https://doi.org/10.1016/j.tele.2015.10.005

Kalatting, S., Serevina, V., \& Astra, I. M 2015. Pengembangan Media Pembelajaran Fisika Berbasis Web Menggunakan Pendekatan Guided Discovery Learning. Jurnal Penelitian \& Pengembangan Pendidikan Fisika, vol. 1, no. 1, pp. 1-8.

Kistner, S., Vollmeyer, R., Burns, B. D., \& Kortenkamp, U 2016. Computers in Human Behavior Model development in scienti fi c discovery learning with a computer- based physics task. Computers in Human Behavior, vol. 59, pp. 446-455. https://doi.org/10.1016/j.chb.2016.02.041

Kurniawati, A \& Sukardiyono 2018. The Development of Authentic Assessment Instrument to Measure Science Process Skill and Achievement based on Students 'Performance. Jurnal Penelitian \& Pengembangan Pendidikan Fisika, vol. 4, no. 2, pp. 65-74.

Lati, W., Supasorn, S., \& Promarak, V 2012. Enhancement of learning achievement and integrated science process skills using science inquiry learning activities of chemical reaction rates. Procedia - Social and Behavioral Sciences, vol. 46, pp. 4471-4475. https://doi.org/10.1016/j.sbspro.2012. 06.279

Lingyi, H 2010. Using GPS to design narrative-centered environments for guided discovery learning : "Façade" - a case study of a nonlinear story. Procedia Social and Behavioral Sciences, vol. 2, no. 2, pp. 4032-4037. https://doi.org/10.1016/j.sbspro.2010.03.636

Makaramani, R 2015. 21 st Century Learning Design for a Telecollaboration Project. Procedia - Social and Behavioral Sciences, vol. 191, pp. 622-627. https://doi.org/10.1016/j.sbspro.2015.04.567

Malik, A 2015. Model Pembelajaran Problem Based Instruction untuk Meningkatkan Penguasaan Konsep dan Keterampilan Proses Sains Mahasiswa. Jurnal Penelitian Dan Pengembangan Pendidikan Fisika, vol. 1, no. 1, pp. 9-16.

Nilawati, W., \& Akbar, N 2017. Perangkat Perkuliahan Terpadu Berbasis KPS untuk Meningkatkan Kompetensi Mahasiswa Pendidikan Fisika Mengembangkan Lembar Kerja Siswa. Jurnal Penelitian Dan Pengembangan Pendidikan Fisika, vol. 3, no. 1, pp. 103-110.

Price, S., \& Falcão, T. P 2011. Interacting with Computers Where the attention is : Discovery learning in novel tangible environments. Interacting with Computers, vol. 23, no. 5, pp. 499-512. https://doi.org/10.1016/j.intcom.2011.06.003

Saab, N., Joolingen, W. R. V. A. N., \& Hout-wolters, B. H. A. M. V. A. N 2007. Supporting Communication in a Collaborative Discovery Learning Environment: the Effect of Instruction. Instructional Science. vol.35, no. 1, pp. 73-98. https://doi.org/10.1007/s11251-006-9003-4

Saribas, D., \& Bayram, H 2009. Is it possible to improve science process skills and attitudes towards chemistry through the development of metacognitive skills embedded within a motivated chemistry lab ?: a self-regulated learning approach. Procedia - Social and Behavioral Sciences, vol. 1, no. 1, pp. 61-72. https://doi.org/10.1016/j.sbspro.2009.01.014

Schachner, A., Zhu, L., Li, J., \& Kelemen, D 2017. Is the bias for function-based explanations culturally universal ? Children from China endorse teleological explanations of natural phenomena. Journal of Experimental Child Psychology, vol. 157, pp. 29-48. https://doi.org/10.1016/j.jecp.2016.12.006 
Susanti, D 2017. Science Process Skills-Based Integrated Instructional Materials to Improve Student Competence Physics Education Prepares Learning Plans on Teaching Skills Lectures. Jurnal Penelitian Dan Pengembangan Pendidikan Fisika, vol. 3, no.1, pp. 35-42.

Thorngate, S 2018. Orientation as Exploration: Video Game Training Modules as a Model for Learning by Discovery. In Planning Academic Library Orientations. https://doi.org/10.1016/B9780-08-102171-2.00006-4

Yamashita, K., Fujioka, R., Kogure, S., Noguchi, Y., Konishi, T., \& Itoh, Y 2016. Practices of algorithm education based on discovery learning using a program visualization system. Research and Practice in Technology Enhanced Learning. vol. 11, no. 15, https://doi.org/10.1186/s41039016-0041-5

Yusuf, M., \& Wulan, A. R 2015. Penerapan Model Pembelajaran Discovery Learning Menggunakan Pembelajaran Tipe Shared dan Webbed untuk Meningkatkan Keterampilan Proses Sains. Jurnal Penelitian \& Pengembangan Pendidikan Fisika, vol. 1, no.2, pp. 19-26. 
